\title{
Larval growth, development and duration in terrestrial hermit crabs
}

\author{
Katsuyuki Hamasaki ${ }^{1, *}$, Saori Kato ${ }^{1}$, Yu Murakami ${ }^{1}$, Shigeki Dan ${ }^{2}$, Shuichi Kitada ${ }^{1}$ \\ ${ }^{1}$ Graduate School of Marine Science and Technology, Tokyo University of Marine Science and Technology, Konan, Minato, \\ Tokyo 108-8477, Japan \\ ${ }^{2}$ Tamano Laboratory, National Research Institute of Fisheries and Environment of Inland Sea, Fisheries Research Agency, \\ Tamano, Okayama 706-0002, Japan
}

\begin{abstract}
We investigated patterns of larval growth and development in terrestrial hermit crabs of the family Coenobitidae (genera Coenobita and Birgus). Larvae of 5 species (C. cavipes, C. purpureus, C. rugosus, C. violascens, and B. latro) were cultured individually at $\sim 28^{\circ} \mathrm{C}$, and their moulting, growth and developmental duration were analysed in conjunction with published data for coenobitid species (C. brevimanus, C. cavipes, C. clypeatus, C. compressus, C. purpureus, C. rugosus, C. scaevola, C. variabilis, and B. latro). Coenobitid crabs metamorphosed into megalopae after 2 to 7 zoeal stages, and intraspecific variability in developmental pathways (number of zoeal stages) was observed in 6 out of 10 species. Interspecific variability in body lengths was large at hatching but reduced in megalopae. Linear growth equations $(y=a+b x)$ between number of moults $(x)$ and body length $(y)$ in the zoeal stages were determined, parameters $a$ and $b$ representing body length at hatching and mean growth increment at moulting, respectively. The relationship between parameters $a$ and $b$ for the species examined suggested the existence of 4 larval growth and development patterns in coenobitids: (1) initially smaller larvae and smaller growth increments - longer pathway; (2) initially smaller larvae and larger growth increments shorter pathway; (3) initially larger larvae and smaller growth increments - shorter pathway; and (4) initially largest larvae and smallest growth increments - shortest pathway (abbreviated development). Total zoeal duration increased with decreasing water temperatures and increasing number of zoeal stages and was apparently unrelated to the geographical distribution of coenobitid species.
\end{abstract}

KEY WORDS: Coconut crab · Land hermit crab - Intraspecific variation · Interspecific variation · Larval duration

\section{INTRODUCTION}

Many marine benthic invertebrates develop via complex life cycles comprising embryonic, meroplanktonic larval, and benthic juvenile-adult phases (Anger 2006). In general, pelagic larval duration determines the length of time that larvae are subject to movement by ocean currents, and therefore it is correlated with larval dispersal distance in the sea (Shanks et al. 2003, O'Connor et al. 2007, Shanks

\footnotetext{
${ }^{*}$ Corresponding author: hamak@kaiyodai.ac.jp
}

2009). Many benthic decapod crustaceans pass through a planktonic zoeal stage, the duration of which is determined by the number of moults, intermoult period, and body size increment at moulting. They then metamorphose into a megalopa, during which the transition from the plankton to the benthos takes place (Anger 2001, 2006). The number of zoeal instars/stages varies between and among species within evolutionary constraints (Knowlton 1974, Rice 1980, Hines 1986, Anger 2001, 2006). Megalopae

() The authors 2015. Open Access under Creative Commons by Attribution Licence. Use, distribution and reproduction are unrestricted. Authors and original publication must be credited. 
may actively select a suitable habitat for settlement by detecting abiotic and biotic environmental stimuli such as changes in temperature and salinity, and chemical cues derived from conspecific adults and/or nursery areas (Anger 2001, 2006, Forward et al. 2001). Therefore, the duration of zoeal and megalopal stages should have an effect on population connection and geographical distribution of species through dispersal and recruitment processes.

Terrestrial hermit crabs of the family Coenobitidae comprise 16 species of land hermit crabs of the genus Coenobita Latreille, 1829 (McLaughlin et al. 2010), and the coconut crab Birgus latro (Linnaeus, 1767). They mainly occur in subtropical and tropical coastal regions (Hartnoll 1988). The coconut crab is the only species in the genus Birgus, and is free from gastropod shells except for a juvenile stage that has the shell-carrying habit of its hermit crab ancestors (Reese 1968, Hamasaki et al. 2011, 2014b). It is the largest terrestrial arthropod and has been an important local resource for human consumption (Brown \& Fielder 1991). However, coconut crab populations have been severely depleted on most inhabited islands because of overharvesting and habitat loss (Amesbury 1980, Brown \& Fielder 1991, Drew et al. 2010). The coconut crab is globally protected, and was first listed as 'Vulnerable' under the IUCN Red List, but was recently categorised as 'Data deficient' in that list - not because the species had recovered but because of the lack of available data (Eldredge 1996, Drew et al. 2010). Land hermit crabs are also the subject of conservation concerns due to their exploitation as ornamental animals (Nakasone 2001, Pavia 2006).

Although coenobitid species are fully terrestrial, females return to the sea to hatch their eggs (Hartnoll 1988, Brown \& Fielder 1991, Nakasone 2001), and their larvae develop through planktonic zoeal stages to a megalopa (Nakasone 1988a, Harvey 1992, Brodie \& Harvey 2001, Wang et al. 2007, Hamasaki et al. 2009, 2013), similar to marine hermit crab species. After settlement, like marine hermit crabs (Reese 1962, Hazlett \& Provenzano 1965), megalopae of terrestrial coenobitid crabs recognise and co-opt gastropod shells before migrating onto land (Reese 1968, Harvey 1992, Brodie 1999, 2002, Hamasaki et al. 2011). Therefore, information on larval growth, development and duration before metamorphosis into the megalopae is essential for a better understanding of the geographical distribution and population connection of coenobitid species, which in turn have implications for conservation of populations.
The number of zoeal stages, zoeal duration, and body length at zoeal and megalopal stages based on laboratory rearing have been reported for 9 coenobitid species: C. brevimanus Dana, 1852 (Hamasaki et al. 2014a), C. cavipes Stimpson, 1858 (Shokita \& Yamashiro 1986, Nakasone 1988a), C. clypeatus (Fabricius, 1787) (Provenzano 1962), C. compressus H. Milne-Edwards, 1836 (Brodie \& Harvey 2001), C. purpureus Stimpson, 1858 (Nakasone 1988a), C. rugosus H. Milne-Edwards, 1837 (Shokita \& Yamashiro 1986, Nakasone 1988a), C. scaevola (Forskål, 1775) (Al-Aidaroos \& Williamson 1989), C. variabilis McCulloch, 1909 (Harvey 1992), and B. latro (Reese \& Kinzie 1968, Wang et al. 2007, Hamasaki et al. 2009, Sugizaki et al. 2010). These studies demonstrated intra- and interspecific variations in the number of zoeal stages, i.e. the developmental pathway to reach the megalopa stage. However, use of an individual culture method whereby the moulting history of individual larvae reared in separate compartments is followed (Brodie \& Harvey 2001) has been applied for 5 species only: C. brevimanus (Hamasaki et al. 2014a), C. clypeatus (Provenzano 1962), C. compressus (Brodie \& Harvey 2001), C. scaevola (AlAidaroos \& Williamson 1989) and C. variabilis (Harvey 1992). Reese \& Kinzie (1968) also employed the individual culture method for larval rearing of $B$. latro, but their data were based mainly on group culture, which cannot follow the moulting history of individual larvae.

Wang et al. (2007) compared the larval development of 8 coenobitid species in terms of ecological adaptation, taking adult habitats, body length of the glaucothoe (=megalopae), and zoeal life span (number of zoeal stages) into consideration. They categorised 4 development types: mangrove adaptation, larger glaucothoe adaptation, smaller glaucothoe adaptation, and hypersaline adaptation. However, the interspecific variation in the body length at hatching was not taken into account, and the relationship between larval body length and number of zoeal stages was not analysed thoroughly.

Our objective with this study was to investigate patterns of larval growth and development in coenobitid species. Larvae of 5 species (C. cavipes, C. purpureus, C. rugosus, C. violascens Heller, 1862, and Birgus latro), whose ovigerous females can be found and collected in subtropical Japan, were cultured individually, and their moulting, growth and developmental duration were analysed in conjunction with published data for coenobitid species (C. brevimanus, C. cavipes, C. clypeatus, C. compressus, C. purpureus, C. rugosus, C. scaevola, C. variabilis, and B. latro). 


\section{MATERIALS AND METHODS}

\section{Larval source}

All species belonging to the genus Coenobita in Japan are recognised collectively as a Natural Monument, to promote their conservation. Therefore, Coenobita species were collected and cultured with the permission of the Agency for Cultural Affairs, Ministry of Education, Culture, Sports, Science and Technology of Japan. In addition, the coconut crab is listed as 'Vulnerable' in the Red Data Book by the Ministry of the Environment of Japan. Therefore, after the end of the culture experiments, collected crabs were returned to their natural habitats.

Culture experiments were conducted in the laboratory at the Tokyo University of Marine Science and Technology during the reproductive season of each species from 2009 to 2011. Ovigerous females of $C$. cavipes, C. purpureus, C. rugosus, C. violascens, and Birgus latro were captured by hand during late June to early July on Hatoma Island $\left(24^{\circ} 28^{\prime} \mathrm{N}, 123^{\circ} 49^{\prime} \mathrm{E}\right)$, Ishigaki Island $\left(24^{\circ} 23-31^{\prime} \mathrm{N}, 124^{\circ} 07-18^{\prime} \mathrm{E}\right)$, and/or Miyako Island $\left(24^{\circ} 43-50^{\prime} \mathrm{N}, 1^{\circ} 5^{\circ} 15-21^{\prime} \mathrm{E}\right)$, Okinawa Prefecture, southern Japan. They were transported to the laboratory by air and maintained in tanks equipped with land space and a sea area (artificial seawater, $\sim 34 \%$ o salinity; Sealife, Marinetech) until hatching occurred at $\sim 28^{\circ} \mathrm{C}$ in air according to the method of Hamasaki et al. (2009) and Hamasaki (2011). Females hatched their eggs into the seawater $\left(\sim 28^{\circ} \mathrm{C}\right)$ in tanks at night and the newly hatched larvae ( $0 \mathrm{~d}$ old) were collected from the tank using a 11 beaker in the early morning.

\section{Larval culture}

The larvae hatched from 2 females, designated as Broods 1 and 2, were cultured for each species. Two groups, each including 30 newly hatched larvae (total 60) randomly selected from each brood, were prepared. The first group of larvae was used for body length measurements, and the second group of larvae for examining survival and moulting history. Larvae were housed individually in the wells of 10 sixwell cell culture plates (10 $\mathrm{ml}$ seawater in each well). The culture medium and conditions, artificial seawater controlled at $\sim 28^{\circ} \mathrm{C}$ and $\sim 34 \%$ salinity and a photoperiod in the culture room of 13-14 h light:11-10 h dark, were similar to the natural conditions during the reproductive season. Larvae were fed Artemia sp. and the rotifer Brachionus plicatilis species com- plex. Artemia (Utah strain) aged 2 d were enriched with a commercial material containing n-3 highly unsaturated fatty acids (SCP, Chlorella Industry) for $4 \mathrm{~h}$ and then fed to the larvae at 2 individuals $\mathrm{ml}^{-1}$. The rotifer $B$. plicatilis species complex, cultured with the phytoplankton Chlorella vulgaris containing n-3 highly unsaturated fatty acids in its cells (Super Chlorella V12, Chlorella Industry), was also given to the crab larvae at 40 individuals $\mathrm{ml}^{-1}$. The larvae were transferred to clean culture wells with fresh seawater and food daily, and each larval moulting was determined by the presence of an exuvia. No larvae fed on their exuviae.

The larvae of each zoeal and megalopal stage (2-5 specimens, depending on the survivors from each brood of each species) were randomly sampled from the first culture group, and fixed with $5 \%$ neutral formalin for $1 \mathrm{~d}$ and then preserved in $70 \%$ ethanol. In C. cavipes, megalopae were also sampled from the second culture group because of the limited number of larvae in the first group. The specimens of finalstage zoeae and megalopae in the minor developmental pathway were not sampled for some species and/or broods because of the limited number of final stage zoeae or use of megalopae for other culture studies. Body length measurements of the specimens were made using a microscope equipped with a digital camera and image analysing system (Nikon Digital Sight and NIS-Elements software) as previously described for larvae of coenobitid crabs (e.g. see Wang et al. 2007) (see Fig. S1 in the Supplement for body length measurements; www.int-res.com/ articles/suppl/s001p093_supp.pdf). Total length (TL) was measured from the tip of the rostrum to the midpoint of the telson excluding the telson processes, and carapace length (CL) was measured from the tip of the rostrum to the posteromedial margin of the carapace.

\section{Data sources}

Larval growth and developmental patterns were compared among 5 species cultured in this study using moulting and growth data including developmental pathway (number of zoeal stages before metamorphosing into the megalopal stage), body lengths (TL and CL) and intermoult period (days) of each stage, and total zoeal duration (number of days required from hatching to moulting to the megalopa). The same data from 2 broods of $C$. brevimanus whose larvae were reared using the same culture protocol by the present authors (Hamasaki et al. 2014a) were also 
included in our analysis. In addition, previously published larval moulting and growth data including developmental pathway, body lengths (TL and CL), intermoult period, and total zoeal duration from individually cultured larvae of 4 species - C. clypeatus (Provenzano 1962), C. compressus (Brodie \& Harvey 2001), C. scaevola (Al-Aidaroos \& Williamson 1989), and C. variabilis (Harvey 1992) - were also included in the analysis. Furthermore, larval developmental pathways from individually cultured larvae of B. latro (Reese \& Kinzie 1968) and total zoeal duration with information of larval rearing temperatures from group-cultured larvae of C. cavipes (Nakasone 1988a), C. purpureus (Nakasone 1988a), C. rugosus (Shokita \& Yamashiro 1986, Nakasone 1988a), and B. latro (Reese \& Kinzie 1968, Wang et al. 2007, Hamasaki et al. 2009) were used for interspecific analysis. Al-Aidaroos \& Williamson (1989) reported that the total zoeal duration of C. scaevola was $47 \mathrm{~d}$, but the summation of the intermoult period (days) of each zoeal stage listed in their Table 1 was $67 \mathrm{~d}$. In the present study, therefore, we adopted $67 \mathrm{~d}$ for the total zoeal duration of C. scaevola. The data from the literature were mean values (with standard deviations) or median values in the range. In the coenobitid crabs, intra- and interspecific comparisons of larval growth based on body length metrics could be made because larvae keep very similar body shapes during zoeal stages in each species and body shapes of zoeae and megalopae are very similar among species (Provenzano 1962, Reese \& Kinzie 1968, Shokita \& Yamashiro 1986, Nakasone 1988a, Al-Aidaroos \& Williamson 1989, Harvey 1992, Brodie \& Harvey 2001, Hamasaki et al. 2014a). Larval rearing conditions such as water temperature, salinity, food, initial stocking number of larvae, and water volume of culture containers are summarised for all species in Table S1 in the Supplement.

\section{Statistical analysis}

All statistical analyses were performed with R language (R3.1.0; R Development Core Team 2014) with a $5 \%$ significance level. We applied a generalised linear mixed-effects model (GLMM) (Everitt 2005, Everitt \& Hothorn 2009, Zuur et al. 2009) with the Gaussian family (identical link) distribution to examine the differences of body length represented by TL among 6 species reared in our laboratory. In this analysis, species was the categorical explanatory variable and brood number of each species was included as a random intercept effect. Similarly, the
GLMM with the Poisson family (logarithmic link) distribution was performed to evaluate the differences in total zoeal duration among 6 species. The statistical significance of the explanatory variable was evaluated with a Wald $\chi^{2}$-test (Poisson family) or a Wald $F$-test with Kenward-Roger degrees of freedom (Kenward \& Roger 1997, Halekoh \& Højsgaard 2013) (Gaussian family) using the Anova function (type II) implemented in the car package (Fox \& Weisberg 2011), and the glmer (Poisson family) or lmer (Gaussian family) function in the lme4 package (Bates et al. 2014). The total zoeal duration between different developmental pathways in C. cavipes Brood 1 and in C. purpureus Brood 2 were compared with a likelihood ratio test using the Anova function and the glm function for a generalised liner model with the Poisson family. This test was not performed for other species/broods with intraspecific variations in developmental pathway because there was only one sample in the minor pathway. The TL of megalopae between different developmental pathways in $C$. cavipes Brood 1 was compared with the $1 m$ function and an $F$-test using the Anova function.

The relationship between 2 variables such as body lengths at hatching and the megalopal stage, and larval body lengths and number of zoeal stages was evaluated using a Pearson product-moment correlation coefficient (r) with a $t$-test.

The linear growth equation, $y=a+b x$, was applied to express the relationship between number of moults $(x)$ and body lengths (TL and CL) $(y)$ in each brood of 6 species $-C$. brevimanus (Hamasaki et al 2014a), and C. cavipes, C. purpureus, C. rugosus, C. violascens, and $B$. latro (present study) - reared in our laboratory, and in individually cultured larvae of 4 species from other studies: C. clypeatus (Provenzano 1962), C. compressus (Brodie \& Harvey 2001), C. scaevola (Al-Aidaroos \& Williamson 1989), and C. Variabilis (Harvey 1992) (total 10 species). The parameters $a$ and $b$ were estimated and evaluated using the $\operatorname{lm}$ function. In this growth model, the value of the explanatory variable (number of moults) ranged from 0 to 6 depending on the species, and parameters $a$ and $b$ represent the body length at hatching and body length increment at moulting, respectively. In the species with intraspecific variations in the developmental pathway, the growth equation was applied to the major developmental pathway in C. cavipes Brood 2, C. purpureus Broods 1 and 2, and C. rugosus Broods 1 and 2 reared in our laboratory, and C. clypeatus (Provenzano 1962) and C. compressus (Brodie \& Harvey 2001) from other studies, and it was estimated using the combined 
data from both pathways in C. cavipes Brood 1 reared in our laboratory. The body lengths of megalopae were not included in the analyses because megalopae have relatively shorter rostrums than zoeae and the linearity of the growth equation is therefore not supported over the entire larval period. Hierarchical cluster analysis was performed to evaluate patterns in the relationship between initial body length (parameter $a$ ) and growth increment (parameter $b$ ) in 10 coenobitid species. The analyses were conducted using the hclust function with 8 clustering methods (complete linkage, single linkage, group average, centroid, median, Ward [Ward.D, Ward.D2], and McQuitty methods), based on the Euclidean distance calculated from the standardised scores of the respective parameter estimates for TL and CL.

It is well known that temperature significantly affects larval developmental duration in marine organisms, including decapod crustaceans (Anger 2001, O'Connor et al. 2007). In the present study, and in a study on C. brevimanus (Hamasaki et al 2014a), larvae were cultured at $\sim 28^{\circ} \mathrm{C}$, whereas in other studies larval rearing temperatures varied from 21 to $32^{\circ} \mathrm{C}$ (Table S1). Therefore, the relationship between water temperature $(T)$ and total zoeal duration $(D)$ was fitted with the following equation in 10 coenobitid species: $D=K /(T-\alpha)$. This equation, known as Réaumur's Law, is part of the theory of heat summation; the parameters $K$ and $\alpha$ are the so-called 'thermal constant' and 'threshold temperature' for development, respectively, as previously estimated for $B$. latro (Hamasaki et al. 2009). The thermal constant (degree days) is the summation of the effective temperature for development (>threshold temperature) up to a selected biological end point. In this analysis, total zoeal duration tended to increase with an increase in the number of zoeal stages at identical temperatures (see 'Results'). The thermal constant $K$ was therefore expressed as the following function: $K$ $=\beta+\gamma S$, where $S$ is the number of zoeal stages, and $\beta$ and $\gamma$ are parameters. Thus, the relationship between temperature and the total zoeal duration was expressed as: $D=(\beta+\gamma S) /(T-\alpha)$. The parameters $\alpha$, $\beta$ and $\gamma$ were estimated using a non-linear ordinary least squares method and evaluated with a $t$-test.

\section{RESULTS}

\section{Larval developmental pathway}

Larval survival rates to metamorphosis to megalopae were over $80 \%$ in the species cultured in our laboratory excluding Birgus latro (see Fig. S2 in the Supplement at www.int-res.com/articles/suppl/s001 p093_supp.pdf for changes in the number of larvae according to larval stage in each species).

Intraspecific variations in the developmental pathway were not found in Coenobita brevimanus, $C$. violascens, or B. latro, all of which had 4 zoeal stages (Fig. 1A), although one larva of $B$. latro moulted to a stage 5 zoea that died without further moulting (Fig. S2). Larvae of C. purpureus and $C$. rugosus moulted to the megalopal stage through stage 4 or 5 zoeae with the major developmental

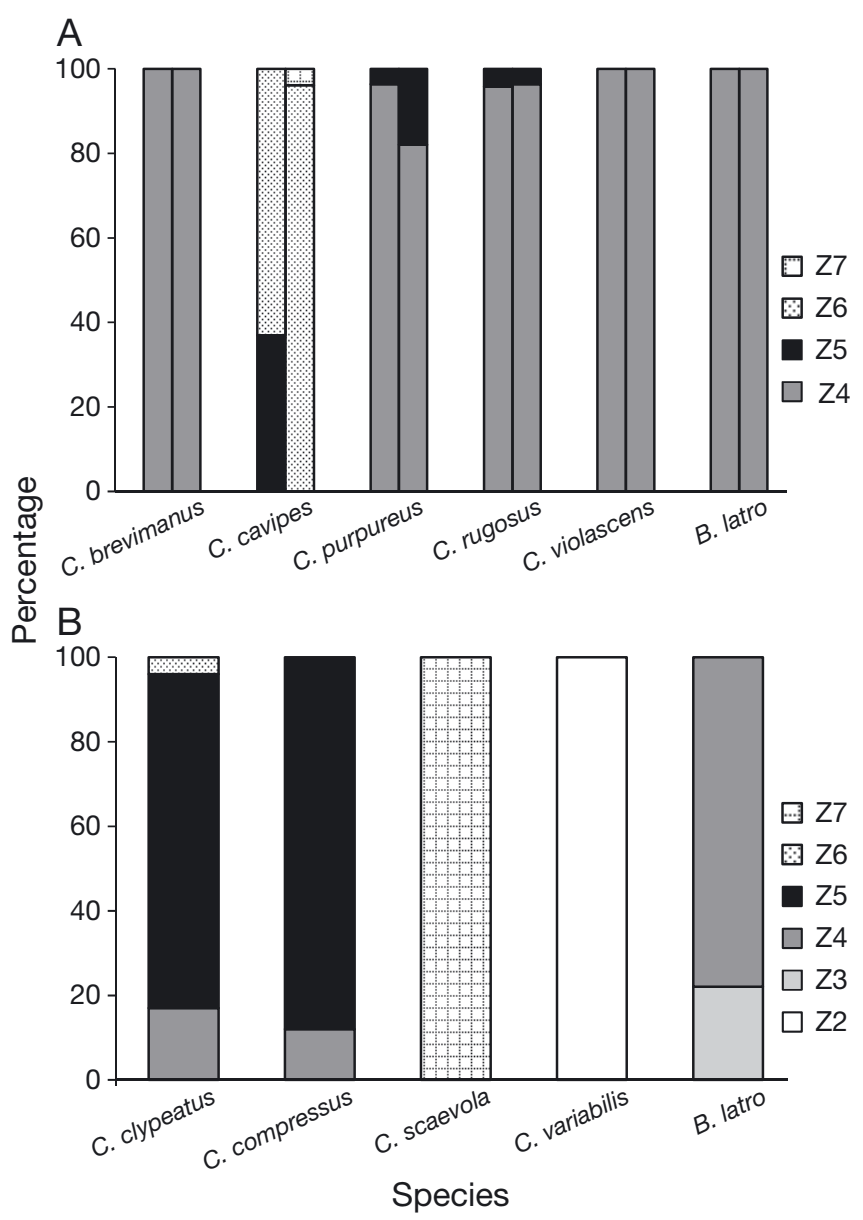

Fig. 1. Composition of larval developmental pathways in Coenobita spp. and Birgus latro. Data are shown for (A) individually cultured larvae from 2 broods of 6 species, C. brevimanus (Hamasaki et al. 2014a), and C. cavipes, C. purpureus, C. rugosus, C. violascens, and B. latro (present study), reared in our laboratory (left and right bars are from Broods 1 and 2, respectively), and (B) individually cultured larvae of 5 species, C. clypeatus (Provenzano 1962), C. compressus (Brodie \& Harvey 2001), C. scaevola (Al-Aidaroos \& Williamson 1989), C. variabilis (Harvey 1992), and B. latro (Reese \& Kinzie 1968). Larval developmental pathway: number of zoeal stages required to metamorphose into the megalopal stage (Z2-Z7: second to seventh zoeal stages) 
pathway through the stage 4 zoeae. C. cavipes had longer developmental pathways with variations in the different broods: 5 or 6 zoeal stages (mostly 6) in Brood 1, and 6 or 7 zoeal stages (mostly 6) in Brood 2.

The numbers of zoeal stages of other Coenobita species based on individual culture results were as follows (Fig. 1B): C. clypeatus, 4, 5 or 6 stages (mostly 5) (Provenzano 1962); C. compressus, 4 or 5 stages (mostly 5) (Brodie \& Harvey 2001); C. scaevola, 7 stages (Al-Aidaroos \& Williamson 1989); C. variabilis, 2 stages (Harvey 1992); and B. latro, 3 or 4 stages (mostly 4) (Reese \& Kinzie 1968). Thus, intraspecific variability in developmental pathways was observed in individually cultured larvae of 6 out of 10 coenobitid species.

\section{Larval growth and development}

The TL of the stage 1 zoeae was significantly different among 6 species cultured in our laboratory $(F=22.62$, df $=5,6.0, \mathrm{p}=0.0007914$; Fig. 2A) (see Table S2 in the Supplement for all body length data). Mean or median TL of the stage 1 zoeae is also shown for 4 described coenobitid species in Fig. 2B (see Table S3 in the Supplement for all body length data). Coenobita variabilis, with abbreviated, lecithotrophic larval development (2 zoeal stages) (Harvey 1992), was much larger at hatching than the other species. Thus, interspecific variation of TL at hatching was large and the coefficient of variation (CV) was calculated at $28 \%$ using the average (or median) values of the respective species.
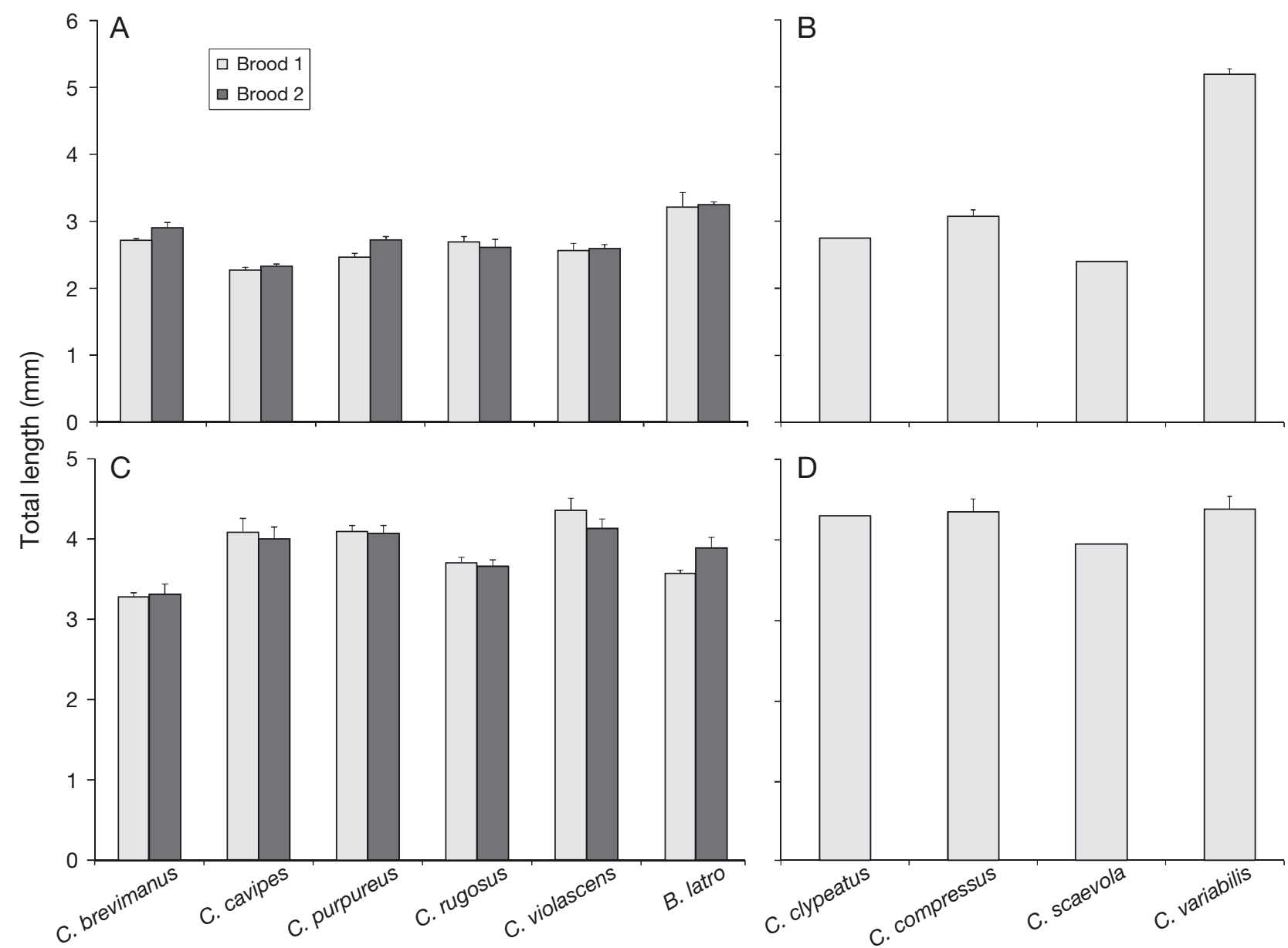

Fig. 2. Total length of the $(\mathrm{A}, \mathrm{B})$ stage 1 zoeae and $(\mathrm{C}, \mathrm{D})$ megalopae in Coenobita spp. and Birgus latro. Total length was measured from the tip of the rostrum to the midpoint of the telson, excluding the telson processes. (A,C) Mean values are shown for individually cultured larvae from 2 broods of 6 species, C. brevimanus (Hamasaki et al. 2014a), and C. cavipes, C. purpureus, C. rugosus, C. violascens, and B. latro (present study), reared in our laboratory. (B,D) Mean values or median values in the range are shown for individually cultured larvae of 4 species, C. clypeatus (Provenzano 1962), C. compressus (Brodie \& Harvey 2001), C. scaevola (Al-Aidaroos \& Williamson 1989), and C. variabilis (Harvey 1992). Vertical bars indicate the standard deviations. See Fig. S1 in the Supplement for body length dimensions, and Tables S2 and S3 in the Supplement for data on body length measurements of each species (www.int-res.com/articles/suppl/s001p093_supp.pdf) 
The TL of the megalopae between the different developmental pathways was not significantly different in $C$. cavipes Brood $1(F=0.6531$, df $=1$, $8, \mathrm{p}=0.6531$ ). The megalopal TL was, however, significantly different among the 6 species $(F=$ 17.79, df $=5,6.0, \mathrm{p}=0.001552$; Fig. 2C). However, the trend of differences in the initial TL of the species (Fig. 2A,B) was not found at the megalopal stage (Fig. 2C,D), and the interspecific variation in the TL was largely reduced as shown by the lower CV value (9\%). Therefore, a significant relationship between the initial TL and megalopal TL was not found (Table 1). This trend was also observed even after excluding $C$. variabilis, with abbreviated larval development, from the analysis (Table 1).

The number of zoeal stages in the major developmental pathway was negatively correlated with TL at hatching but not with megalopal TL (Table 1). This result may be biased by including $C$. variabilis, which has a much larger size at hatching and 2 zoeal stages, in the analyses. However, a similar trend was found in the relationship between the number of zoeal stages and larval TL even after excluding $C$. variabilis from the analyses (Table 1). Therefore, initial larval body length appears to determine the developmental pathway in coenobitid species, and initially smaller/larger larvae require more/fewer moults to reach a given body length at the megalopal stage.

The linear growth equations expressing the relationship between number of moults and body length (TL and CL) were a good fit for the zoeal stages of 10 species (Fig. 3 and see Tables S4 \& S5 in the Supplement for parameter estimates and statistics). Parameter a represents the initial body length of larvae, as illustrated by the same trend in the interspecific variability between the values of initial TL (Fig. 2A,B) and estimates of parameter a for TL (Fig. 4A,B). Parameter $b$ represents the mean growth increment at moulting and tended to be lowest in C. variabilis, followed by C. scaevola and C. cavipes, and larger in C. purpureus, C. rugosus, and C. violascens (Fig. 4C,D).

The linear growth equations include information on 3 important early life-history traits: initial body length, growth increment at moulting, and number of moults to the megalopal stage (developmental pathway). Initial body length tended to be negatively correlated with the number of zoeal stages before moulting to the megalopal stage as mentioned above. Here, to see the relationship between the initial body length and growth increment in larvae of 10 coenobitid species, estimates of parameter $a$ are plotted against those of parameter $b$ for TL and CL in Fig. 5. Based on these parameter estimates, 7 out of 8 clustering methods resulted in similar dendrograms that categorise 4 groups $(2$ representative dendrograms are shown in Fig. 6; see Fig. S3 in the Supplement for other dendrograms). Characteristics of these 4 groups are summarised as follows: (1) species with initially smaller larvae and smaller growth increments, showing longer developmental pathways (C. cavipes, mostly 6 stages; C. scaevola, 7); (2) species with initially smaller larvae and larger growth increments, showing shorter developmental pathways (C. purpureus, mostly $4 ;$ C. rugosus, mostly $4 ; C$. violascens, 4); (3) species with initially larger larvae and smaller growth increments, showing shorter developmental pathways (C. brevimanus, 4; C. clypeatus, mostly 5; C. compressus, mostly 5; B. latro, mostly 4); and (4) species with initially largest larvae and smallest growth increments, showing the shortest developmental pathway (abbreviated development) (C. variabilis, 2).

Table 1. Pearson product-moment correlation coefficient (r) of the relationship among total length (TL) of the stage 1 zoeae, TL of megalopae, and number of zoeal stages in the major developmental pathway in 10 coenobitid species:, Coenobita brevimanus, C. cavipes, C. clypeatus, C. compressus, C. purpureus, C. rugosus, C. scaevola, C. variabilis, C. violascens, and Birgus latro

\begin{tabular}{|lcrrrr}
\hline Variables & Species analysed & $r$ & df & $t$ & p \\
\hline Initial zoeal TL and megalopal TL & All species & 0.199 & 15 & 0.758 & 0.4609 \\
& Excluding C. variabilis & -0.246 & 14 & -0.914 & 0.3771 \\
Initial zoeal TL and number of zoeal stages & All species & -0.689 & 15 & -3.557 & 0.0031 \\
& Excluding C. variabilis & -0.510 & 14 & -2.136 & 0.0523 \\
Megalopal TL and number of zoeal stages & All species & 0.049 & 15 & 0.183 & 0.8572 \\
& Excluding C. variabilis & 0.300 & 14 & 1.132 \\
\hline
\end{tabular}


100

Sex Early Dev Aquat Org 1: 93-107, 2015
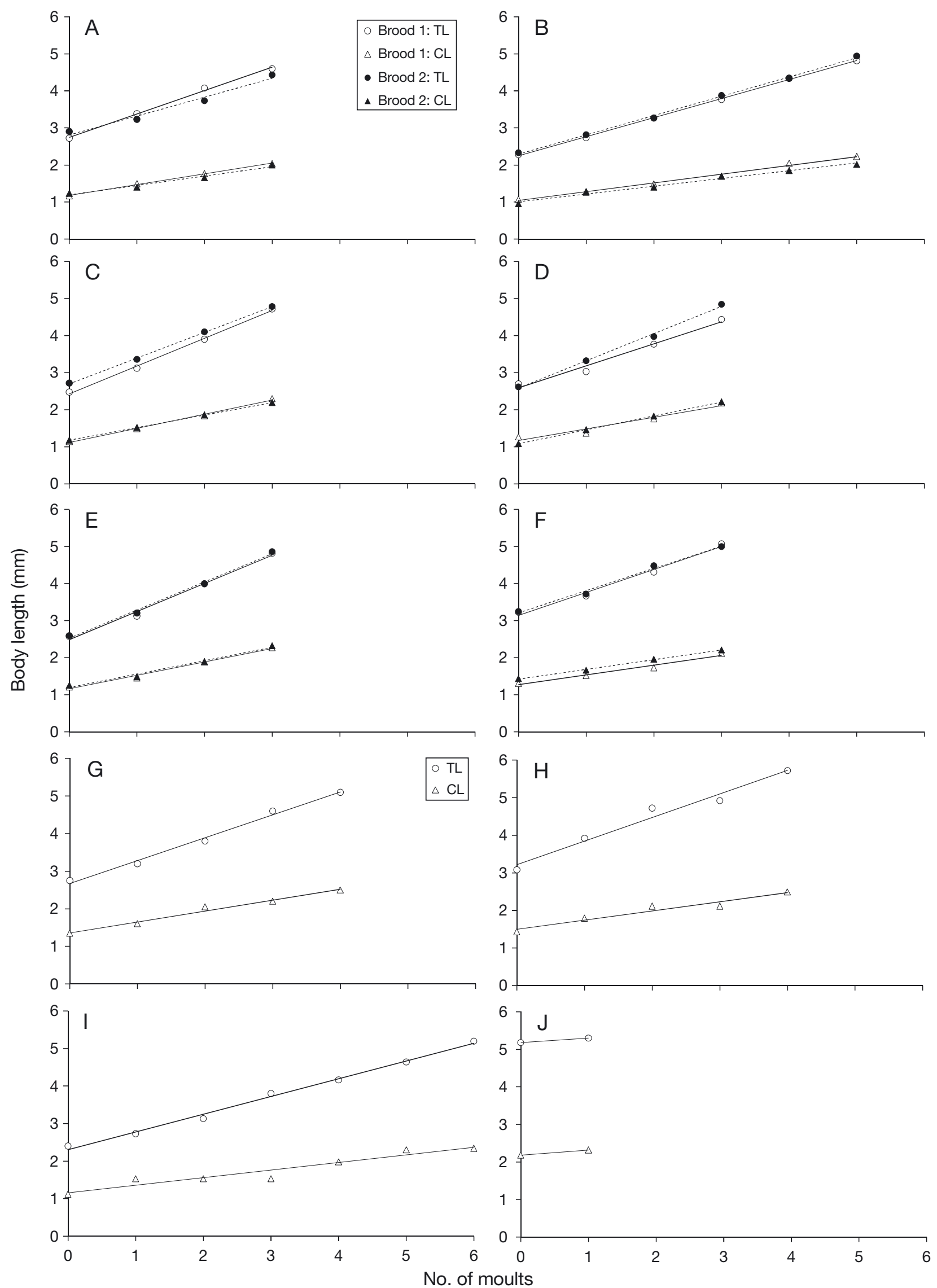
Fig. 3. Growth expressed by the relationship between number of moults and body length in Coenobita spp. and Birgus latro. Mean values of body lengths (total length [TL] and carapace length [CL]) are shown for individually cultured larvae of 2 broods of 6 species, (A) C. brevimanus (Hamasaki et al. 2014a), and (B) C. cavipes, (C) C. purpureus, (D) C. rugosus, (E) C. violascens, and (F) B. latro (present study), reared in our laboratory, and mean values or median values in the range of TL and CL for individually cultured larvae of 4 species, (G) C. clypeatus (Provenzano 1962), (H) C. compressus (Brodie \& Harvey 2001), (I) C. scaevola (Al-Aidaroos \& Williamson 1989), and (J) C. variabilis (Harvey 1992). TL was measured from the tip of the rostrum to the midpoint of the telson, excluding the telson processes. CL was measured from the tip of the rostrum to the posteromedial margin of the carapace. Solid and dotted lines in A-F correspond to Broods 1 and 2, respectively. See Fig. S1 in the Supplement for body length dimensions, and Tables S4 \& S5 in the Supplement for parameter estimates of the linear growth equations (www. int-res.com/articles/suppl/s001p093_supp.pdf)

\section{Larval duration}

The intermoult periods of larvae before the final zoeal stage were 3-5 d on average, and they increased to 5-9 $\mathrm{d}$ in the final stage in 6 species (Fig. 7; see Table S6 in the Supplement for larval duration). This trend, i.e. increasing the intermoult period in the final zoeal stage, was also observed in C. compressus and C. variabilis (see Table S7 in the Supplement). Average total zoeal duration was the same in the different developmental pathways in $C$. cavipes Brood 1, but tended to be slightly longer in the longer pathway in C. cavipes Brood 2, C. purpureus Broods 1 and 2, and C. rugosus Broods 1 and 2 (Fig. 7). A significant difference was not detected between the 2 pathways in the species/broods for
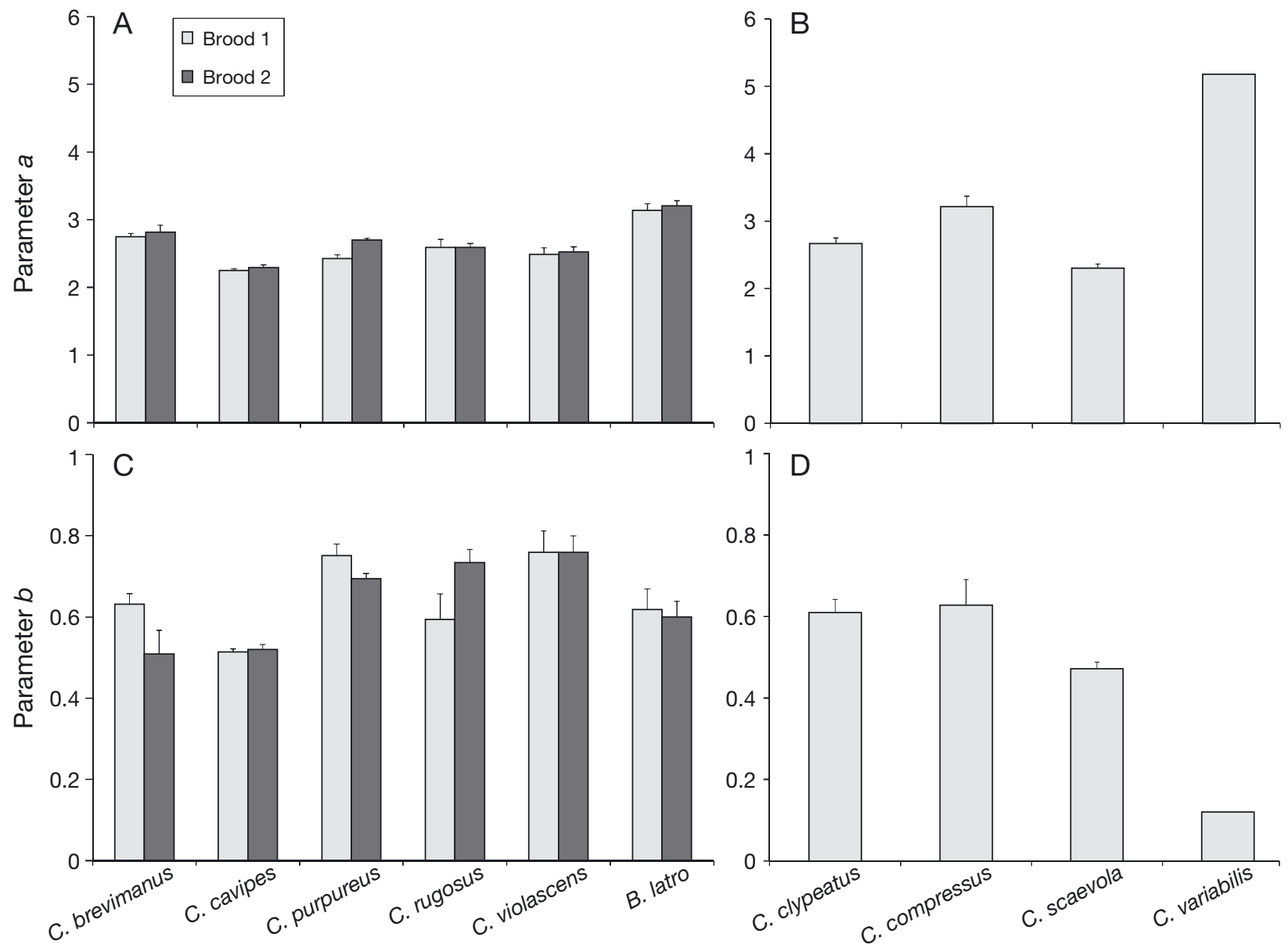

Fig. 4. Estimates of $(A, B)$ parameter $a$ and $(C, D)$ parameter $b$ in the linear growth equations for the relationship between number of moults and body length (total length) in Coenobita spp. and Birgus latro. Estimates are shown for (A,C) individually cultured larvae from 2 broods of 6 species, C. brevimanus (Hamasaki et al. 2014a), and C. cavipes, C. purpureus, C. rugosus, C. violascens, and B. latro (present study), reared in our laboratory, and (B,D) individually cultured larvae of 4 species, C. clypeatus (Provenzano 1962), C. compressus (Brodie \& Harvey 2001), C. scaevola (Al-Aidaroos \& Williamson 1989), and C. variabilis (Harvey 1992). Vertical bars indicate the standard errors. See Tables S4 \& S5 in the Supplement for parameter estimates and statistics for each body length measurement (www.int-res.com/articles/suppl/s001p093_supp.pdf) 


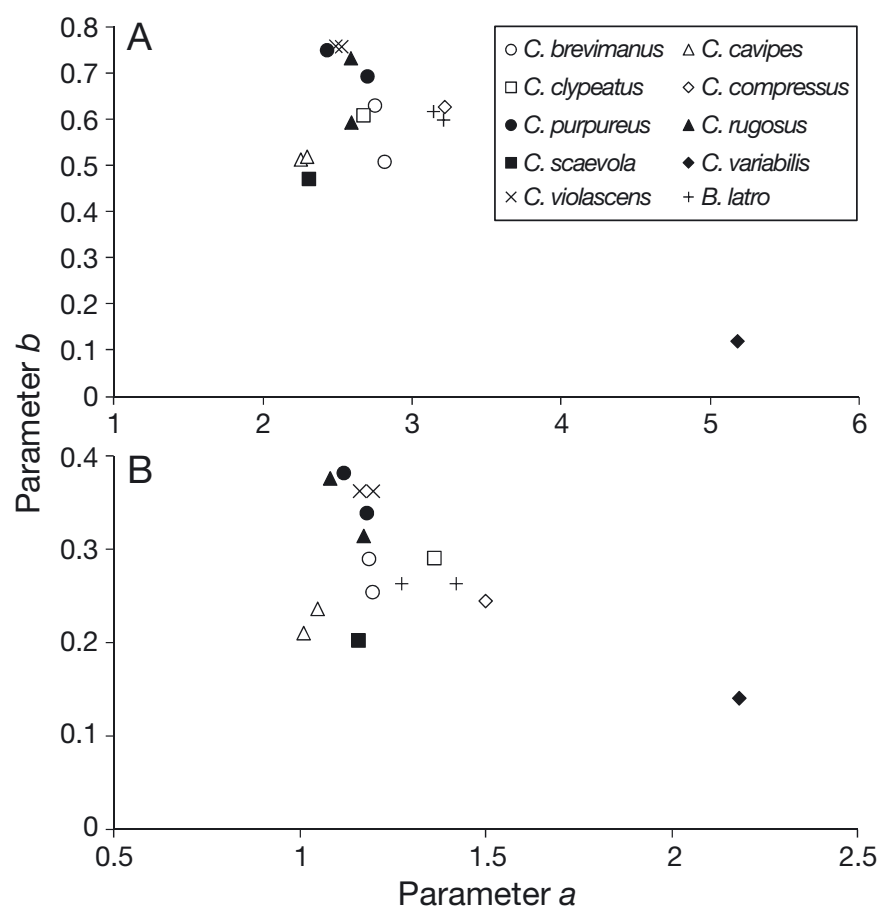

Fig. 5. Relationship between the estimates of parameters $a$ and $b$ in linear growth equations for Coenobita spp. and Birgus latro. Diagrams are shown for (A) total length and (B) carapace length. See Tables S4 \& S5 in the Supplement for parameter estimates of each species (www.int-res.com/ articles/suppl/s001p093_supp.pdf )

which the statistical test was able to be performed (C. cavipes Brood 1: $\chi^{2}=0.00013, \mathrm{df}=1, \mathrm{p}=0.9909$; C. purpureus Brood 2: $\chi^{2}=1.6005, \mathrm{df}=1, \mathrm{p}=0.2058$ ).

Total zoeal duration was significantly different among the 6 species $\left(\chi^{2}=294.8, \mathrm{df}=5, \mathrm{p}<0.0001\right)$; it was longer in C. cavipes (with more zoeal stages) compared with the other species (Fig. 7). In 10 coenobitid species, total zoeal duration tended to decrease with increasing temperature, and it appeared to vary depending on the developmental pathways (Fig. 8): longer duration in C. scaevola with 7 zoeal stages at $25^{\circ} \mathrm{C}$ and shorter duration in C. variabilis with 2 zoeal stages at $25^{\circ} \mathrm{C}$ and $30^{\circ} \mathrm{C}$. Parameters of the heat summation theory equation, $D=(\beta+\gamma S) /(T-\alpha)$, between temperature $(T)$ and total zoeal duration $(D)$ including the number of zoeal stages $(S)$ as the explanatory variable, were estimated as shown in Table 2. Parameters $\alpha$ and $\gamma$ were significantly different from zero, while $\beta$ was not significant.

\section{DISCUSSION}

We successfully conducted the individual culture of larvae at $28^{\circ} \mathrm{C}$ for 6 coenobitid species including

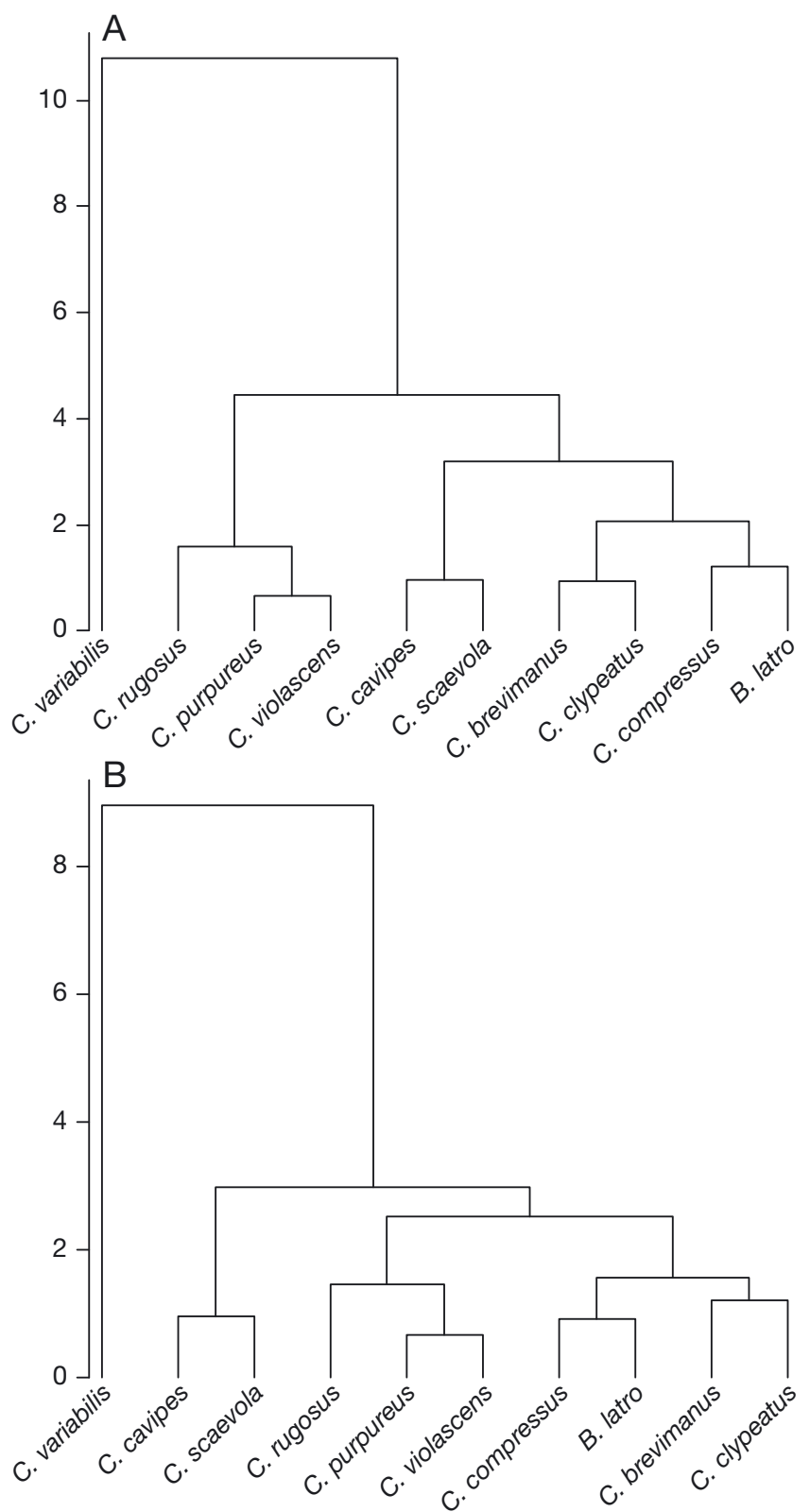

Fig. 6. Dendrograms of 10 coenobitid species (Coenobita spp. and Birgus latro) as defined by cluster analysis with 2 clustering methods, (A) complete linkage and (B) McQuitty, based on the Euclidean distance calculated from the standardised scores of respective parameter estimates in the linear growth equations for total length (TL) and carapace length (CL). See Fig. S3 in the Supplement for dendrograms based on 6 other clustering methods (www.int-res.com/ articles/suppl/s001p093_supp.pdf)

Coenobita brevimanus (Hamasaki et al. 2014a). Furthermore, the larval culture from hatching to the megalopa stage was achieved for the first time for $C$. violascens. Our results and those of previous studies demonstrate intra- and interspecific variation in the larval developmental pathways, with variable larval 

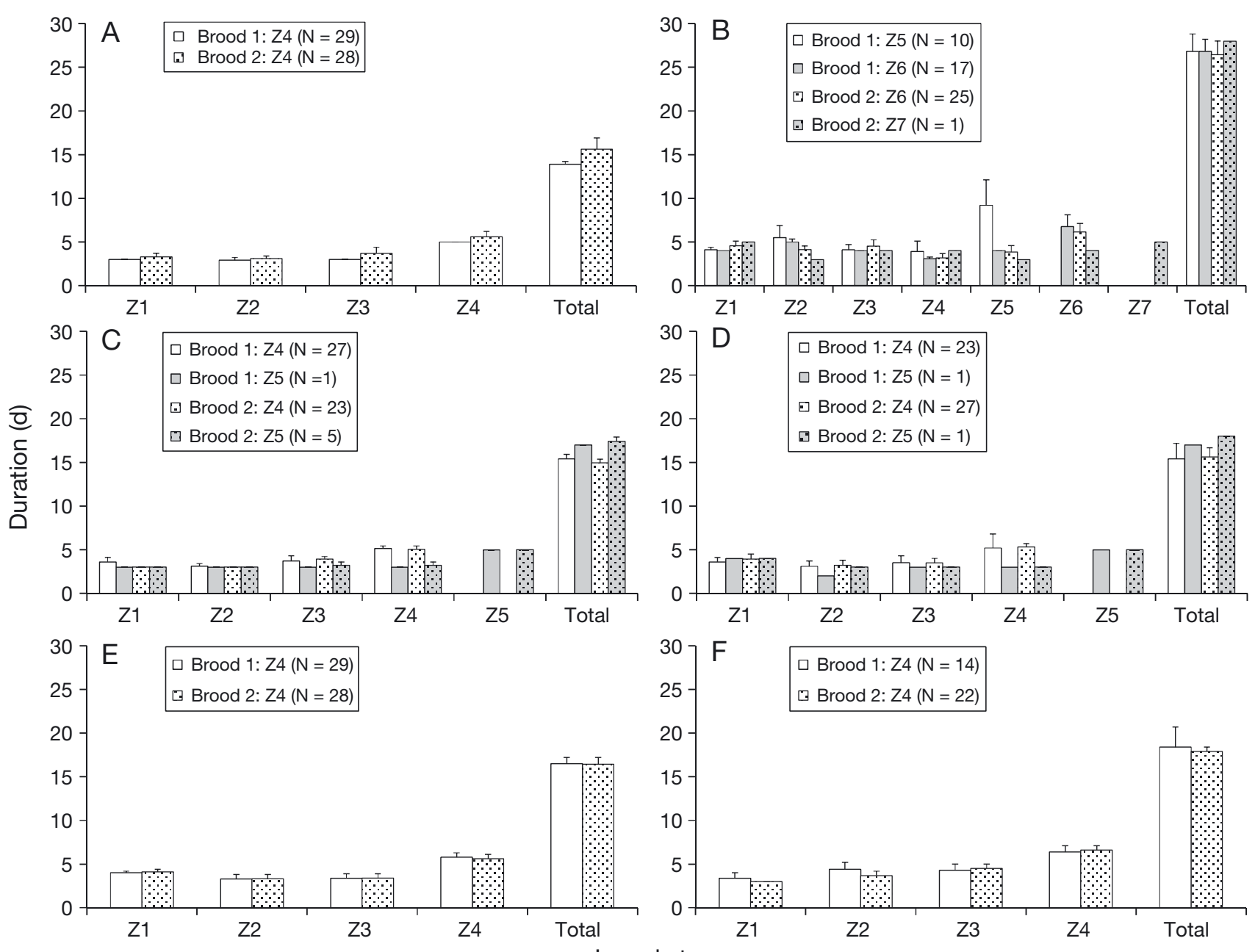

Fig. 7. Larval duration in each zoeal stage and total zoeal duration from hatching to moulting to the megalopal stage in Coenobita spp. and Birgus latro. Mean values are shown for respective developmental pathways in individually cultured larvae from 2 broods of 6 species: (A) C. brevimanus (Hamasaki et al. 2014a), and (B) C. cavipes, (C) C. purpureus, (D) C. rugosus, (E) C. violascens, and (F) B. latro (present study), reared in our laboratory. Vertical bars indicate the standard deviations. Z1-Z7: first to seventh zoeal stages. See Table S6 in the Supplement for data on the larval duration of each species (www.int-res.com/ articles/suppl/s001p093_supp.pdf )

duration depending on water temperature and number of zoeal stages.

\section{Intraspecific variability in larval growth and development}

Laboratory and field studies have reported intraspecific variability in larval developmental pathways of decapod crustaceans (Knowlton 1974, Gore 1985, Anger 2001, 2006). The causes of the variability have been attributed to genetic and maternal factors, and to environmental stress, such as unfavourable salinities, temperatures, and limited nutritional conditions (Anger 2001, Zeng et al. 2004). Our data and that of previously published studies revealed that intraspecific variability in developmental pathways has been observed in individually cultured larvae of 6 out of 10 coenobitid species. Our results also demonstrated that 3 species previously thought to exhibit a constant number of zoeal stages (C. cavipes, C. purpureus, and C. rugosus) (Brodie \& Harvey 2001, Wang et al. 2007) in fact exhibited variability in the number of zoeal stages. Brodie \& Harvey (2001) suspected that the reported lack of variability in the number of zoeal stages in these species might be an artefact of the group culture of larvae.

Knowlton (1974) hypothesised that food energy is utilised for maintenance activities at the expense of the moulting process, which in turn has priority over 


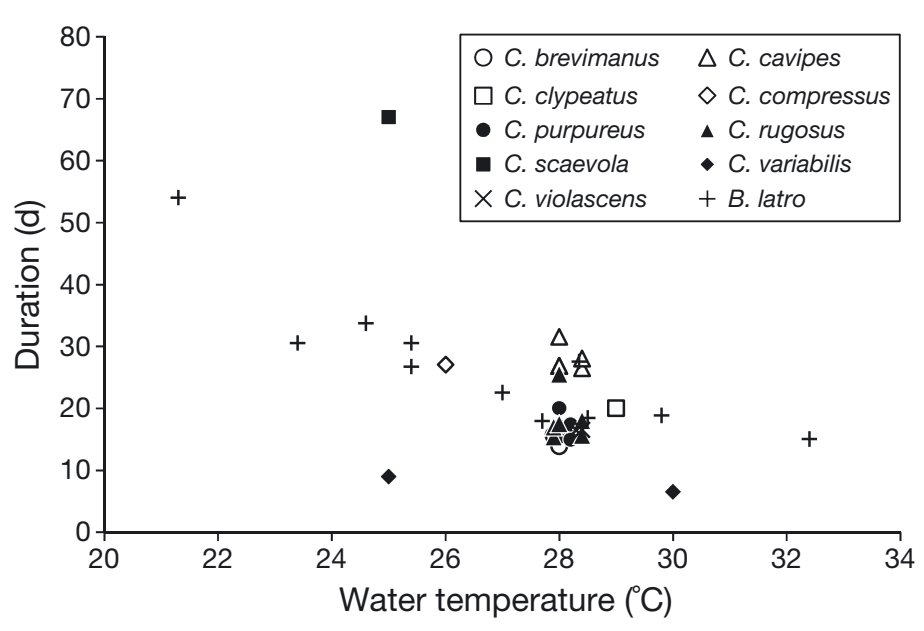

Fig. 8. Relationship between water temperature and total zoeal duration from hatching to moulting to the megalopal stage in Coenobita spp. and Birgus latro. Data sources are as follows: individually cultured larvae from 2 broods of 6 species, C. brevimanus (Hamasaki et al. 2014a), and C. cavipes, C. purpureus, C. rugosus, C. violascens, and B. latro (present study), reared in our laboratory; individually cultured larvae of 4 species, C. clypeatus (Provenzano 1962), C. compressus (Brodie \& Harvey 2001), C. scaevola (Al-Aidaroos \& Williamson 1989), and C. variabilis (Harvey 1992); and group-cultured larvae of $C$. cavipes (Nakasone 1988a), C. purpureus (Nakasone 1988a), C. rugosus (Shokita \& Yamashiro 1986, Nakasone 1988a), and B. latro (Reese \& Kinzie 1968, Wang et al. 2007, Hamasaki et al. 2009)

growth and morphogenesis, resulting in a longer developmental pathway under environmental stress. Anger (2001) stated that the optimal temperature range for rearing larvae of subtropical and tropical crab species is usually $>25^{\circ} \mathrm{C}$, whereas temperatures $<20^{\circ} \mathrm{C}$ increase larval mortality. Hamasaki et al. (2009) conducted group culture of Birgus latro larvae at 6 different temperatures $\left(\sim 19-32^{\circ} \mathrm{C}\right)$ and found that stage 5 zoeae that died without further moulting occurred in groups with lower survival rates at temperatures lower than $25^{\circ} \mathrm{C}$. In the present study, larval mortality rate tended to be high in $B$. latro compared with other species, and a stage 5 zoea that died without further moulting occurred in Brood 1.

Table 2. Parameter estimates with standard errors (SE) of the heat summation theory equation, $D=(\beta+\gamma S) /(T-\alpha)$, between temperature $(T)$ and total zoeal duration $(D)$, including the number of zoeal stages $(S)$ in 10 coenobitid species. The number of data points for estimating parameters was 36

\begin{tabular}{|lrrrr|}
\hline Parameter & Estimate & \multicolumn{1}{c}{ SE } & $t$ & \multicolumn{1}{c|}{$p$} \\
\hline$\alpha$ & 18.01 & 0.58 & 31.316 & $<0.0001$ \\
$\beta$ & -43.01 & 35.53 & -1.211 & 0.2350 \\
$\gamma$ & 55.27 & 8.22 & 6.724 & $<0.0001$ \\
\hline
\end{tabular}

Accordingly, it is suggested that the intraspecific variation in the larval developmental pathways of subtropical and tropical coenobitid crabs might be attributed to environmental stress (e.g. lower water temperatures), different nutritional conditions of individual larvae under identical rearing conditions, and/or maternal factors.

Larval culture studies under the various environmental and nutritional conditions are still needed to evaluate the flexibility in the developmental pathways of species for which variability in developmental pathways has not been reported: C. brevimanus, C. scaevola, and C. violascens-excluding C. variabilis, which exhibits abbreviated larval development. Furthermore, we could not evaluate the intraspecific growth variations in individually cultured larvae of coenobitid species because we sampled larvae at each zoeal stage and the subsequent developmental pathway of these larvae could therefore not be known. Thus, our larval growth data were derived from the major developmental pathways. To understand the variability in relationships between growth and developmental pathways at the individual larva level, another approach to obtaining the measurements, e.g. measuring exuviae after moulting, would be necessary in future studies.

\section{Interspecific variability in larval growth and development}

Larger maternal investment in individual larvae facilitates larval development of the estuarine crab Neohelice (Chasmagnathus) granulata and the caridean shrimp Palaemonetes varians through shorter pathways (Giménez \& Torres 2002, Giménez \& Anger 2003, Giménez et al. 2004, Oliphant \& Thatje 2013, Oliphant et al. 2013). Variability in larval development patterns mediated by body length variation at hatching was observed at the interspecific level in the coenobitid species; initially, smaller larvae of $C$. cavipes and C. scaevola had longer developmental pathways, whereas the largest larvae of $C$. variabilis underwent abbreviated larval development.

Wang et al. (2007) categorised 4 larval development types in coenobitids based on adult habitats, body length of the glaucothoe (=megalopae), and number of zoeal stages: (1) mangrove adaptation $(C$. variabilis, 2 stages); (2) larger glaucothoe adaptation (C. cavipes, C. clypeatus, C. compressus and C. purpureus, 4-6); (3) smaller glaucothoe adaptation $(C$. rugosus and B. latro, 3-5); and (4) hypersaline adaptation (C. scaevola, 7). However, they categorised the 
species mainly based on the megalopal body length and/or adult habitats, and did not analyse the relationship between larval body length and number of zoeal stages. Our analyses implied that the number of zoeal stages was not determined by megalopal body length, but was influenced by the body length at hatching, indicating that larvae did not have longer developmental pathways to achieve the larger body length at the megalopal stage. Besides body length at hatching, growth increment at moulting was also associated with the larval developmental pathway. The relationship between parameters $a$ and $b$ in the linear growth equation between number of moults and body length for the species examined suggested the existence of 4 larval growth and development patterns in coenobitids: (1) species with initially smaller larvae and smaller growth increments - longer pathway (C. cavipes and C. scaevola); (2) species with initially smaller larvae and larger growth increments - shorter pathway (C. purpureus, C. rugosus, and C. violascens); (3) species with initially larger larvae and smaller growth increments - shorter pathway ( $C$. brevimanus, C. clypeatus, C. compressus, and B. latro); and (4) species with initially largest larvae and smallest growth increments - shortest pathway (abbreviated development) (C. variabilis).

These larval growth and developmental patterns might have evolved to allow environmental adaptation by a species within phylogenetic constraints. One of the fundamental trade-offs in life-history evolution is between size and number of eggs (larvae) (Smith \& Fretwell 1974). Given this, we hypothesise that coenobitid species might have evolved lifehistory traits with variations in the initial body length of larvae. To achieve the given size at the megalopal stage in coenobitid species, in the group with initially smaller larvae, some species with smaller growth increments had longer developmental pathways with a longer zoeal duration (Pattern 1). By contrast, some species increased growth increments, resulting in shorter developmental pathways without extending zoeal duration (Pattern 2). However, some species increased the initial body length while retaining shorter developmental pathways without extending zoeal duration, resulting in smaller growth increments (Pattern 3). In the case of the extreme phenotype in the coenobitids reported so far (Pattern 4), $C$. variabilis evolved to produce the largest larvae at hatching, resulting in abbreviated development with 2 brief, lecithotrophic zoeal stages (Harvey 1992). Although it is not known which pattern of larval growth and development is the ancestral trait, the abbreviated larval development in $C$. variabilis might be considered as a derived character, as previously suggested for some decapod crustaceans (Anger 2001, Wowor et al. 2009).

\section{Larval duration}

Total zoeal durations varied among/within coenobitid species depending on the temperatures and developmental pathways: the shortest duration was observed in C. variabilis, which exhibits abbreviated development $\left(6-7 \mathrm{~d}\right.$ at $\left.30^{\circ} \mathrm{C}\right)$ (Harvey 1992), whereas the longest duration was observed in C. scaevola, with 7 stages $\left(67 \mathrm{~d}\right.$ at $\left.25^{\circ} \mathrm{C}\right)$ (Al-Aidaroos \& Williamson 1989). The geographical occurrence of coenobitid species can be divided into 2 patterns (Hartnoll 1988, Nakasone 1988b, Harvey 1992, Wang et al. 2007): (1) widely distributed species, C. brevimanus, C. cavipes, C. perlatus, C. rugosus, C. violascens, and B. latro in the Indo-Pacific; and (2) species with a relatively narrower distribution, C. clypeatus in the Western Atlantic, C. compressus in the west coast of America from Mexico to Chile, C. purpureus in the Northwestern Pacific adjacent to Japan, $C$. scaevola in the Red Sea, Gulf of Aden, Somalia, and Pakistan, and C. variabilis in Northern Australia. The abbreviated larval development seems to be relevant to the limited geographical distribution in C. variabilis. However, the narrower distribution was observed in C. scaevola, which has the longest developmental pathway of the studied species. Thus, larval duration was apparently unrelated to the geographical distribution of coenobitid species. Studies on the phylogeographic history and oceanographic conditions are needed for a better understanding of speciation and geographical distribution of coenobitid crabs.

Acknowledgements. We thank the Okinawa Prefectural Board of Education for permission to culture the land hermit crabs. We are grateful to the editors, Sven Thatje, and 2 anonymous reviewers for their constructive comments and suggestions, which have improved the manuscript. This study was supported by Grants-in-Aid for Scientific Research C20580198 and B24310171 from the Ministry of Education, Culture, Sports, Science and Technology of Japan.

\section{LITERATURE CITED}

Al-Aidaroos A, Williamson DI (1989) Larval development of the land hermit crab Coenobita scaevola (Forskål, 1775) (Crustacea: Anomura: Coenobitidae) reared in the laboratory. J Nat Hist 23:111-128 
Amesbury SS (1980) Biological studies on the coconut crab (Birgus latro) in the Mariana Islands. Univ Guam Mar Lab Tech Rep 66:1-39

Anger K (2001) The biology of decapod crustacean larvae. Crustacean Issues, Vol 14. A. A. Balkema Publishers, Rotterdam

Anger K (2006) Contribution of larval biology to crustacean research: a review. Invertebr Reprod Dev 49:175-205

Bates D, Maechler M, Bolker B, Walker S, Christensen RHB, Singmann H (2014) lme4: Linear mixed-effects models using Eigen and S4. http://lme4.r-forge.r-project.org/ (accessed 4 May 2014)

$>$ Brodie RJ (1999) Ontogeny of shell-related behaviors and transition to land in the terrestrial hermit crab Coenobita compressus H. Milne Edwards. J Exp Mar Biol Ecol 241: 67-80

> Brodie RJ (2002) Timing of the water-to-land transition and metamorphosis in the land hermit crab Coenobita compressus H. Milne Edwards: evidence that settlement and metamorphosis are de-coupled. J Exp Mar Biol Ecol 272: $1-11$

Brodie R, Harvey AW (2001) Larval development of the land hermit crab Coenobita compressus H. Milne Edwards reared in the laboratory. J Crustac Biol 21:715-732

Brown IW, Fielder DR (1991) Project overview and literature survey. In: Brown IW, Fielder DR (eds) The coconut crab: aspects of Birgus latro biology and ecology in Vanuatu. ACIAR Monograph, No. 8. Australian Centre for International Agricultural Research, Canberra, p 1-11

$>$ Drew MM, Harzsch S, Stensmyr M, Erland S, Hansson BS (2010) A review of the biology and ecology of the robber crab, Birgus latro (Linnaeus, 1767) (Anomura: Coenobitidae). Zool Anz 249:45-67

Eldredge LG (1996) Birgus latro. In: IUCN (2013) IUCN Red List of Threatened Species. www.iucnredlist.org/details/ 2811/0 (accessed 20 June 2014)

Everitt BS (2005) An R and S-Plus companion to multivariate analysis. Springer-Verlag, London

Everitt BS, Hothorn T (2009) A handbook of statistical analyses using R. CRC Press, New York, NY

- Forward RB Jr, Tankersley RA, Rittschof D (2001) Cues for metamorphosis of brachyuran crabs: an overview. Am Zool 41:1108-1122

Fox J, Weisberg S (2011) An R companion to applied regression, 2nd edn. Sage Publications, Thousand Oaks, CA

> Giménez L, Anger K (2003) Larval performance in an estuarine crab, Chasmagnathus granulata, is a consequence of both larval and embryonic experience. Mar Ecol Prog Ser 249:251-264

Giménez L, Torres G (2002) Larval growth in the estuarine crab Chasmagnathus granulata: the importance of salinity experienced during embryonic development, and the initial larval biomass. Mar Biol 141:877-885

Giménez L, Anger K, Torres G (2004) Linking life history traits in successive phases of a complex life cycle: effects of larval biomass on early juvenile development in an estuarine crab, Chasmagnathus granulata. Oikos 104: $570-580$

Gore RH (1985) Molting and growth in decapod larvae. In: Wenner AM (ed) Larval growth, Crustacean Issues, Vol 2. A. A. Balkema Publishers, Rotterdam, p 1-65

Halekoh U, Højsgaard S (2013) pbkrtest: parametric bootstrap and Kenward Roger based methods for mixed model comparison. http://people.math.aau.dk/ sorenh/ software/pbkrtest/ (accessed 4 May 2014)
Hamasaki K (2011) Early life history of coconut crabs inferred from culture experiments. Cancer 20:73-77 (in Japanese)

Hamasaki K, Sugizaki M, Dan S, Kitada S (2009) Effect of temperature on survival and developmental period of coconut crab (Birgus latro) larvae reared in the laboratory. Aquaculture 292:259-263

Hamasaki K, Sugizaki M, Sugimoto A, Murakami Y, Kitada S (2011) Emigration behaviour during sea-to-land transition of the coconut crab Birgus latro: effects of gastropod shells, substrata, shelters and humidity. J Exp Mar Biol Ecol 403:81-89

Hamasaki K, Sugimoto A, Sugizaki M, Murakami Y, Kitada S (2013) Ontogeny of sinking velocity, body density, and phototactic behaviour in larvae of the coconut crab Birgus latro: implications for larval dispersal and recruitment in the sea. J Exp Mar Biol Ecol 442:58-65

- Hamasaki K, Kato S, Hatta S, Murakami Y, Dan S, Kitada S (2014a) Larval development and emigration behaviour during sea-to-land transition of the land hermit crab Coenobita brevimanus Dana, 1852 (Crustacea: Decapoda: Anomura: Coenobitidae) under laboratory conditions. J Nat Hist 48:1061-1084

> Hamasaki K, Ishiyama N, Yamashita S, Kitada S (2014b) Survival and growth of juveniles of the coconut crab Birgus latro under laboratory conditions: implications for mass production of juveniles. J Crustac Biol 34:309-318

Hartnoll RG (1988) Evolution, systematic, and geographical distribution. In: Burggren WW, McMahon BR (eds) Biology of the land crabs. Cambridge University Press, New York, NY, p 6-54

Harvey AW (1992) Abbreviated larval development in the Australian terrestrial hermit crab Coenobita variabilis McCulloch (Anomura: Coenobitidae). J Crustac Biol 12: 196-209

Hazlett BA, Provenzano AJ Jr (1965) Development of behaviour in laboratory reared hermit crabs. Bull Mar Sci 15: 616-633

Hines AH (1986) Larval patterns in the life histories of brachyuran crabs (Crustacea, Decapoda, Brachyura). Bull Mar Sci 39:444-466

Kenward MG, Roger JH (1997) Small sample inference for fixed effects from restricted maximum likelihood. Biometrics 53:983-997

Knowlton RE (1974) Larval developmental processes and controlling factors in decapod Crustacea, with emphasis on Caridea. Thalassia Jugosl 10:138-158

McLaughlin PA, Komai T, Lemaitre R, Rahayu DL (2010) Annotated checklist of anomuran decapod crustaceans of the world (exclusive of the Kiwaoidea and families Chirostylidae and Galatheidae of the Galatheoidea) Part I-Lithodoidea, Lomisoidea and Paguroidea. Raffles Bull Zool Suppl 23:5-107

Nakasone Y (1988a) Larval stages of Coenobita purpureus Stimpson and C. cavipes Stimpson reared in the laboratory and survival rates and growth factors of three land hermit crab larvae (Crustacea: Anomura). Zoolog Sci 5: 1105-1120

Nakasone Y (1988b) Land hermit crabs from the Ryukyus, Japan, with a description of a new species from the Philippines (Crustacea, Decapoda, Coenobitidae). Zoolog Sci 5:165-178

Nakasone Y (2001) Reproductive biology of three land hermit crabs (Decapoda: Anomura: Coenobitidae) in Okinawa, Japan. Pac Sci 55:157-169 
O'Connor MI, Bruno JF, Gaines SD, Halpern BS, Lester SE, Kinlan BP, Weiss JM (2007) Temperature control of larval dispersal and the implications for marine ecology, evolution, and conservation. Proc Natl Acad Sci USA 104: 1266-1271

Oliphant A, Thatje S (2013) Per offspring investment implications for crustacean larval development: evolutionary insights into endotrophy and abbreviated development. Mar Ecol Prog Ser 493:207-217

Oliphant A, Hauton C, Thatje S (2013) The implications of temperature-mediated plasticity in larval instar number for development within a marine invertebrate, the shrimp Palaemonetes varians. PLoS ONE 8:e75785

Pavia A (2006) Hermit crab: your happy health pet. Wiley Publishing, Hoboken, NJ

Provenzano AJ Jr (1962) The larval development of the tropical land hermit crab Coenobita clypeatus (Herbst) in the laboratory. Crustaceana 4:207-228

R Development Core Team (2014) R: a language and environment for statistical computing. R Foundation for Statistical Computing, Vienna

Reese ES (1962) Shell selection behaviour of hermit crabs. Anim Behav 10:347-360

Reese ES (1968) Shell use: an adaptation for emigration from the sea by the coconut crab. Science 161:385-386

Reese ES, Kinzie RA III (1968) The larval development of the coconut or robber crab Birgus latro (L.) in the laboratory (Anomura, Paguridea). Crustaceana Suppl 2:117-144

Rice AL (1980) Crab zoeal morphology and its bearing on the classification of the brachyuran. Trans Zool Soc Lond 35:271-372

Editorial responsibility: Klaus Anger,

Malente, Germany
Shanks AL (2009) Pelagic larva duration and dispersal distance revisited. Biol Bull 216:373-385

> Shanks AL, Grantham BA, Carr MH (2003) Propagule dispersal distance and the size and spacing of marine reserves. Ecol Appl 13:159-169

Shokita S, Yamashiro A (1986) Larval development of the land hermit crabs, Coenobita rugosus H. Milne Edwards and $C$. cavipes Stimpson reared in the laboratory. Galaxea 5:267-282

Smith CC, Fretwell SD (1974) The optimal balance between size and number of offspring. Am Nat 108:499-506

Sugizaki M, Hamasaki K, Dan S, Kitada S (2010) Growth and morphogenesis of larvae reared at different temperatures and mass culture of larvae in the coconut crab Birgus latro. Aquacult Sci 58:135-142

Wang FL, Hsieh HL, Chen CP (2007) Larval growth of the coconut crab Birgus latro with a discussion on the development mode of terrestrial hermit crabs. J Crustac Biol 27:616-625

> Wowor D, Muthu V, Meier R, Balke M, Cai Y, Ng PKL (2009) Evolution of life history traits in Asian freshwater prawns of the genus Macrobrachium (Crustacea: Decapdoa: Palaemonidae) based on mutlilocus molecular phylogenetic analysis. Mol Phylogenet Evol 52:340-350

> Zeng C, Li S, Zeng H (2004) Occurrence of additional ZoeaVI larvae in the mud crab, Scylla paramamosain (Estampador), reared in the laboratory. Hydrobiologia 529: 49-58

Zuur AF, Ieno EN, Walker NJ, Saveliev AA, Smith GM (2009) Mixed effects models and extensions in ecology with R. Springer, New York, NY

Submitted: June 19, 2014; Accepted: November 27, 2014 Proofs received from author(s): February 13, 2015 